\title{
Effectiveness of Stable Ozone Microbubble Water on Reducing Bacteria on the Surface
}

\section{of Selected Leafy Vegetables}

\author{
Yasuhiro Inatsu $^{1 *}$, Tomoko Kitagawa ${ }^{1}$, Nobutaka NaKamura ${ }^{1}$, Susumu Kawasaki ${ }^{1}$, Daisuke Nei ${ }^{1}$, \\ Md. Latiful BARI ${ }^{2}$ and Shinichi KAWAMOTO ${ }^{1}$ \\ ${ }^{1}$ National Food Research Institute, National Agriculture and Food Research Organization, 2-1-12 Kannondai, Tsukuba, Ibaraki 305-8642, \\ Japan \\ ${ }^{2}$ Center for Advanced Research in Sciences, University of Dhaka, Dhaka 1000, Bangladesh
}

Received June 2, 2011; Accepted August 26, 2011

\begin{abstract}
Effectiveness of a novel developed sanitizer, stable ozone microbubble-containing water (ozone microbubble water; OMBW), on reducing 13 kinds of bacteria was evaluated in vitro. The effectiveness of dip inoculated Escherichia coli 0157:H7 or naturally attached bacteria on four kinds of leafy vegetables was also evaluated. For the purpose of comparison, the effectiveness of gaseous ozone (GO), sodium hypochlorite solution $(\mathrm{NaClO})$ and distilled water (DW) were also evaluated. A 5.0 to 7.4 log reduction of viable cells was observed in an in vitro study. In contrast, a 0.8 to 1.2 or 0.9 to $1.8 \log$ CFU/g reduction in $E$. coli viable cells was observed after washing with $\mathrm{OMBW}$ or $\mathrm{NaClO}$, respectively, for all tested leafy vegetables. No significant difference was observed in the effectiveness of OMBW, ozonated water $(\mathrm{OW})$ and $\mathrm{DW}$. No reduction of viable cells was observed after exposure of leaves to GO. Similar experimental results were observed with the naturally attached bacteria. No difference in color and appearance was observed with DW and other sanitizing treatments. These results suggest that the effectiveness of OMBW in surface decontamination of leafy vegetables is similar to that of $\mathrm{OW}$.
\end{abstract}

Keywords: ozone microbubble water, ozonated water, E. coli $\mathrm{O} 157: \mathrm{H} 7$, surface decontamination

\section{Introduction}

Consumption of fresh produce has been suggested to increase public health because fresh vegetables and fruits are thought to be an important part of a healthy diet and are a source of much-needed vitamins, minerals and fiber. Typically, most fruits, vegetables, and ready-to-eat (RTE) foods sold in markets rarely carry pathogenic bacteria. However, there is always the possibility of contamination with food borne pathogens, such as enterohemorrhagic Escherichia coli O157:H7, during any stage of product handling from production at the farms to the point of sale (Hanning et al., 2009; Matthews 2006). Naturally contaminated bacteria, such as Bacillus sp., Enterobacter sp., Erwinia sp., Flavobacterium sp. and Pseudomonas sp., among others, are related to the spoilage of fresh produce during transportation and storage (Bari et al., 2005; Barth et al., 2009; Heard 2002). Thus, the

*To whom correspondence should be addressed. E-mail: inatu@affrc.go.jp effectiveness of many kinds of surface-washing sanitizers have been evaluated on fresh produce(Gil et al., 2009).

Sodium hypochlorite $(\mathrm{NaClO})$ is commonly used for surface decontamination of fresh produce to reduce the risk of food poisoning or spoilage because of its broad spectrum of antimicrobial activity, ease of application and low cost (Sapers, 2006). This compound is usually used for surface decontamination of foods at levels of $50-200 \mathrm{mg} / \mathrm{L}$ free chlorine and with a typical contact time of less than $5 \mathrm{~min}$ (Rico et al., 2007). However, chlorine is highly corrosive and may damage stainless steel equipment after prolonged exposure. Furthermore, its rapid depletion in the presence of a high organic load and concerns over the potential carcinogenicity of compounds resulting from the reaction of the active hypochlorite with nitrogen-containing compounds have prompted the consideration of alternative disinfectants (Wei et al., 1985; Buschini et al., 2004). An acidified sodium chlorite solution produced by mixing sodium chlorite $\left(\mathrm{NaClO}_{2}\right)$ and acid in water has been proposed as a candidate alterna- 
tive sanitizer (Inatsu et al., 2010b; Elano et al., 2010; Nei et al., 2009; Stopforth et al., 2008).

Ozone $\left(\mathrm{O}_{3}\right)$ is a strong antimicrobial compound with a high oxidative activity. In addition, it spontaneously decomposes into a non-toxic product (Rico et al., 2007). In contrast to hypochlorous acid ( $\mathrm{HClO})$, ozone does not effectively penetrate the cell; however, it causes damage to the cell wall structure on the outside of the cell and eliminates the exposed bacteria (Cho et al., 2010). Theoretically, the maximum concentration of dissolved ozone gas in water at $20^{\circ} \mathrm{C}$ and $0.10 \mathrm{MPa}$ is $570 \mathrm{mg} / \mathrm{L}$, and only a limited portion $(10-50$ $\mathrm{mg} / \mathrm{L}$ ) of the generated ozone exists due to the evaporation loss from water and its short half-life (1-10 min) (Dhillon et al., 2009). Ozonated water (OW) exhibits more than a 5.0 $\log \mathrm{CFU} / \mathrm{mL}$ bactericidal activity against Gram-positive and -negative foodborne pathogens in liquid cultures (Restaino et al., 1995). The effectiveness of the OW to control the growth of surface-attached E. coli O157:H7 or natural flora on vegetables has been investigated (Beltran et al., 2005; Singh et al., 2002; Zhang et al., 2005; Koseki and Isobe, 2006).

Recently, a novel commercially available sanitizer, i.e., a stable ozone microbubble-containing water (ozone microbubble water; OMBW), was purchased and applied to food hygiene control and the elongation of shelf life for foods (Nakamura and Shiina 2010); however, only limited scientific studies have been conducted on OMBW. In general, the diameter of the bubbles are mechanically produced on a 100$\mu \mathrm{m}$ scale by using the flow pump or supersonic method (Xu et al., 2008). However, at this size, the dispended bubbles are not stable and can be easily crushed, or they can surface. Recently, Takahashi et al. (2003) developed stable microbubbles of less than $10 \mu \mathrm{m}$ in diameter (Takahashi et al., 2003; Takahashi, 2005). One of the benefits of smaller bubbles in water is that they can remain stably dispended in water for longer periods of time (i.e., over several months). The purpose of this study was to evaluate the effectiveness of OMBW on reducing the viable cell count of surface-attached bacteria on leafy vegetables or in vitro.

\section{Material and Methods}

Bactericidal effectiveness of ozone microbubble water in vitro The experimental methods were the same as previously published(Inatsu et al., 2010a), except for small modifications. The ozone microbubble water (OMBW) was purchased from Nano Industry Development Co. Ltd. (Miyagi, Japan) and was used within a month. The 13 bacterial strains analyzed in this study are listed in Table 1. The JCM and ATCC strains were purchased from Japan Collection of Microorganism and American Type Culture Collection, respectively. Four E. coli O157:H7 strains (CR-3, MN-
28, MY-29 and DT-66) were isolated from calf feces. The organisms were grown in brain heart infusion (BHI: Nissui Pharmaceutical Co. Ltd, Tokyo) agar plates or on de Man, Rogosa and Sharpe (MRS: Becton and Dickinson, USA) agar plates for lactic acid bacteria. Fresh cultures in the early stationary growth phase were prepared with BHI or MRS broth and were used for the assays after being washed twice in phosphate buffered saline (PBS). The washed cells were exposed to OMBW or PBS for $3 \mathrm{~min}$. After treatment, viable cells were measured using the surface spread or pour plate method. The cells were then incubated for 24 to $48 \mathrm{~h}$ at $35^{\circ} \mathrm{C}$ or $30^{\circ} \mathrm{C}$ for Listeria monocytogenes and lactic acid bacteria, respectively. This experiment was repeated at least five times to confirm reproducibility. The statistical differences of $\log$ reduction between each of the tested strains were analyzed by Tukey-Kramer's multiple comparison tests.

Bactericidal effectiveness of ozone microbubble water on vegetable leaves The experimental methods were the same as previously described (Elano et al., 2010; Nei et al., 2009; Inatsu et al., 2010b) except for small modifications. OW was generated with a flow-type electric ozone generator (Do30, Kobe Steel, Ltd., Kobe, Japan) and was used within 5 min. The concentration of dissolved or dispended ozone was measured based on the indigo method(Kondo et al., 2005). A sterile, distilled water solution (DW) was used for the control study. The gaseous ozone (GO) was generated by a discharge ionization machine (Ozonizer EO-1, Navi Engineering Co. Ltd., Yokohama, Japan).

Lettuce (Lactuca sativa), Chinese cabbage (Brassica rapa ssp. Chinensis), spinach (Spinacia oleracea) and cabbage (Brassica oleracea) were purchased from supermarkets in Tsukuba city, Japan, between February and August 2009. Each of the leafy vegetables (650 g) was cut into $3 \times$ $3 \mathrm{~cm}$ square pieces and mixed well in a plastic bag. For the inoculation study, each of the vegetables was dipped into a mixture of four spontaneous rifampicin resistance $E$. coli O157:H7 strains (i.e., CR-3, MN-28, MY-29 and DT-66) ( 7.2 to $7.7 \log \mathrm{CFU} / \mathrm{mL}$ ) and dried for $1 \mathrm{~h}$. The inoculated or non-inoculated vegetables (150 g) were submerged into 1.50 L of washing solution in a 3-L plastic beaker for $3 \mathrm{~min}$ with gentle mixing by a glass rod. The washing water was removed using a salad spinner for $1 \mathrm{~min}$, and the viable cells of the samples were enumerated by the pour plate method after 1 min of subjection to a stomacher machine (Gunze industry, MC-D type 400D). The residual bactericidal activity of the washing solution was also measured by exposing PBS-washed E. coli cells for 3 min (Inatsu et al., 2010a; Elano et al., 2010). Instead of the washing treatment, exposing the vegetables to $100 \mathrm{mg} / \mathrm{L}$ of $\mathrm{GO}$ in plastic bags was also performed. A standard agar plate and desoxycholate agar 
was used to enumerate the aerobic plate count (APC) and coliform bacteria, respectively. A $50 \mathrm{mg} / \mathrm{L}$ rifampicin solution containing trypticase soy agar (TSA) and sorbitol MacConkey agar (SMAC) were used for the recovery of $E$. coli O157:H7. All media used in this experiment were purchased from Nissui Pharmaceutical Co. Ltd.

The leafy vegetables described above were washed in four batches for each of the washing solutions. These experiments were repeated six times on different days using different lots of vegetables purchased from different shops. The experimental results $(n=24)$ were subjected to statistical analysis by Turkey-Kramer's multiple comparison tests. We also analyzed the results of the four types of vegetables by analysis of variance (ANOVA) with the Fisher method.

Sensory evaluation The appearance and color of the sanitizer-treated vegetables were compared to water-washed vegetables by the three-point discrimination test (triangle sensory test) (Stone and Sidel, 2004). Twenty well-trained panelists ( 9 males and 11 females) from the National Food Research Institute were asked to identify a sample that they thought to be able to distinguish from among three samples. More than 11 correct answers from 20 panelists showed the existence of a statistically significant difference $(\mathrm{P}<0.05)$ between sanitizer-treated samples and the control.

\section{Results and Discussion}

To evaluate the bactericidal effectiveness of the ozone microbubble water (OMBW) sanitizer, we performed in vitro experiments on 13 kinds of bacteria (Table 1). A reduction of 5.0 to $7.4 \log \mathrm{CFU} / \mathrm{mL}$ of viable cells was observed after $3 \mathrm{~min}$ of exposure to this sanitizer $\left(5.44 \mathrm{mg} / \mathrm{L} \mathrm{O}_{3}\right)$ at $25^{\circ} \mathrm{C}$. Pseudomonas aeruginosa and Staphylococcus aureus showed statistically lower $(\mathrm{P}<0.05)$ sensitivities compared to the other tested strains using this sanitizer. A similar ten-

Table 1. Bactericidal activity of ozone microbubble water in vitro.

\begin{tabular}{|c|c|c|c|}
\hline Strains & \multicolumn{3}{|c|}{ Viable cell counts (log reduction) (log CFU/mL) } \\
\hline Escherichia coli CR-3 (O157:H7) & $\begin{array}{c}\text { PBS } \\
\text { OMBW }\end{array}$ & $\begin{array}{l}8.7 \pm 0.1 \\
1.3 \pm 0.0\end{array}$ & $(7.4 \pm 0.1)^{\mathrm{A}}$ \\
\hline Salmonella Enteritidis JCM1652 & $\begin{array}{c}\text { PBS } \\
\text { OMBW }\end{array}$ & $\begin{array}{l}8.6 \pm 0.1 \\
1.9 \pm 0.8\end{array}$ & $(6.8 \pm 0.8)^{\mathrm{A}}$ \\
\hline Klebsiella pneumoniae JCM1662 ${ }^{\mathrm{T}}$ & $\begin{array}{c}\text { PBS } \\
\text { OMBW }\end{array}$ & $\begin{array}{l}8.7 \pm 0.1 \\
1.5 \pm 0.6\end{array}$ & $(7.2 \pm 0.6)^{\mathrm{A}}$ \\
\hline Citrobacter freundii JCM1657 & $\begin{array}{c}\text { PBS } \\
\text { OMBW }\end{array}$ & $\begin{array}{l}8.8 \pm 0.2 \\
2.1 \pm 0.9\end{array}$ & $(6.7 \pm 1.0)^{\mathrm{A}}$ \\
\hline Cronobacter sakazakii JCM1233 ${ }^{\mathrm{T}}$ & $\begin{array}{c}\text { PBS } \\
\text { OMBW }\end{array}$ & $\begin{array}{l}8.6 \pm 0.1 \\
2.6 \pm 0.9\end{array}$ & $(6.0 \pm 0.9)^{\mathrm{A}}$ \\
\hline Pseudomonas aeruginosa $\mathrm{JCM} 5962^{\mathrm{T}}$ & $\begin{array}{c}\text { PBS } \\
\text { OMBW }\end{array}$ & $\begin{array}{l}8.4 \pm 0.3 \\
3.3 \pm 0.5\end{array}$ & $(5.0 \pm 0.6)^{\text {B }}$ \\
\hline Listeria monocytogenes ATCC13932 & $\begin{array}{c}\text { PBS } \\
\text { OMBW }\end{array}$ & $\begin{array}{l}8.4 \pm 0.1 \\
1.3 \pm 0.0\end{array}$ & $(7.1 \pm 0.1)^{\mathrm{A}}$ \\
\hline Staphylococcus aureus JCM2413 & $\begin{array}{c}\text { PBS } \\
\text { OMBW }\end{array}$ & $\begin{array}{l}8.6 \pm 0.2 \\
3.0 \pm 0.5\end{array}$ & $(5.5 \pm 0.6)^{B}$ \\
\hline Enterococcus faecalis JCM8726 ${ }^{\mathrm{T}}$ & $\begin{array}{c}\text { PBS } \\
\text { OMBW }\end{array}$ & $\begin{array}{l}7.7 \pm 0.5 \\
1.3 \pm 0.0\end{array}$ & $(6.4 \pm 0.5)^{\mathrm{A}}$ \\
\hline Leuconostoc mesenteroides JCM6124 ${ }^{\mathrm{T}}$ & $\begin{array}{c}\text { PBS } \\
\text { OMBW }\end{array}$ & $\begin{array}{l}8.2 \pm 0.2 \\
2.1 \pm 0.9\end{array}$ & $(6.1 \pm 1.0)^{\mathrm{A}}$ \\
\hline Lactobacillus plantarum JCM1149 & $\begin{array}{c}\text { PBS } \\
\text { OMBW }\end{array}$ & $\begin{array}{l}8.3 \pm 0.3 \\
2.9 \pm 0.9\end{array}$ & $(5.5 \pm 0.9)^{\mathrm{AE}}$ \\
\hline Pediococcus pentosaceus JCM5890 ${ }^{\mathrm{T}}$ & $\begin{array}{c}\text { PBS } \\
\text { OMBW }\end{array}$ & $\begin{array}{l}7.7 \pm 1.0 \\
2.7 \pm 1.1\end{array}$ & $(5.0 \pm 1.5)^{\mathrm{AE}}$ \\
\hline Lactococcus lactis JCM5805 & $\begin{array}{c}\text { PBS } \\
\text { OMBW }\end{array}$ & $\begin{array}{l}7.6 \pm 0.2 \\
2.0 \pm 0.8\end{array}$ & $(5.5 \pm 0.9)^{\mathrm{A}}$ \\
\hline
\end{tabular}

Cells washed with phosphate buffered saline (PBS) were exposed to ozone micro bubble water (OMBW) or PBS for 3 $\min$. The average and standard deviation of the logarithmic number of enumerated viable cells are shown $(n>6)$. The different letters on the shoulder of the log reduction value indicate significant difference $(\mathrm{P}<0.05)$. 
dency in tolerance difference to ozonated water (OW) treatment in vitro was also reported by Restaino et al. (1995). The different tolerances to ozone (microbubble) water exposure seen among tested strains may reflect differences in cellular responses used to deal with the oxidative stress caused by the ozone, or the amount of enzymes decomposed by the ozone.

To confirm the efficacy of the decontamination of surface-attached bacteria on four kinds of leafy vegetables, we conducted washing experiments of native or E. coli $\mathrm{O} 157: \mathrm{H} 7$ inoculated samples. The average level of contamination of aerobic mesophilic bacteria and coliform bacteria on the four kinds of vegetables before washing were 4.7 (cabbage) to 6.5 (spinach) $\log$ CFU/g and 3.6 (cabbage) to 5.9 (spinach) $\log$ $\mathrm{CFU} / \mathrm{g}$, respectively (Table 2). Among the four tested vegetables, Chinese cabbage and spinach exhibited higher viable bacterial counts compared to lettuce and cabbage. Washing the vegetables with $\mathrm{DW}$ for $3 \mathrm{~min}$ at $25^{\circ} \mathrm{C}$ reduced the viable aerobic bacteria and the coliform bacteria by less than $1.0 \log$ $\mathrm{CFU} / \mathrm{g}$ for each of the tested vegetables. The use of OW (4.64 $\left.\mathrm{mg} / \mathrm{L} \mathrm{O}_{3}\right)$ or OMBW $\left(5.44 \mathrm{mg} / \mathrm{L} \mathrm{O}_{3}\right)$ instead of DW did not show any additional bactericidal effectiveness for all tested vegetables. Washing the vegetables with a $100 \mathrm{mg} / \mathrm{L} \mathrm{NaClO}$ solution reduced the naturally contaminating bacteria by approximately $2.0 \log \mathrm{CFU} / \mathrm{g}$ in all tested vegetables. However, exposure to $100 \mathrm{mg} / \mathrm{L} \mathrm{GO}$ for $3 \mathrm{~min}$ did not reduce the viable bacterial cell count on the tested vegetables, except for the aerobic mesophilic bacteria in cabbage. No significant differences $(P>0.05)$ in the effectiveness of viable bacterial cell reduction were observed between each of the four types of vegetables. The color and appearance of all tested vegetables after each treatment did not differ significantly compared to the water-washed samples (Table 3).

Similar results were obtained in the case of artificially inoculated E. coli O157:H7 on the surface of vegetables (Table

Table 2. Bactericidal effectiveness of sanitizers on naturally attached bacteria on leafy vegetables.

\begin{tabular}{|c|c|c|c|c|c|c|}
\hline & \multicolumn{6}{|c|}{ Viable cell counts of aerobic methophilic bacteria (log CFU/g) } \\
\hline & Before washing & Distilled water & $\begin{array}{c}\text { Sodium } \\
\text { hypochlorite }\end{array}$ & $\begin{array}{l}\text { Ozone micro } \\
\text { bubble water }\end{array}$ & Ozonated water & Gaseous ozone \\
\hline Lettuce & $5.1 \pm 0.4^{\mathrm{A}}$ & $4.4 \pm 0.7^{\mathrm{B}}$ & $3.3 \pm 0.7^{\mathrm{C}}$ & $4.2 \pm 0.6^{\mathrm{B}}$ & $4.3 \pm 0.4^{\mathrm{B}}$ & $5.1 \pm 0.6^{\mathrm{AB}}$ \\
\hline Chinese cabbage & $6.4 \pm 0.6^{\mathrm{A}}$ & $5.9 \pm 0.5^{\mathrm{A}}$ & $4.4 \pm 0.8^{\mathrm{C}}$ & $5.2 \pm 0.4^{\mathrm{B}}$ & $5.4 \pm 0.2^{\text {в }}$ & $5.8 \pm 0.6^{\mathrm{AB}}$ \\
\hline Spinach & $6.5 \pm 0.4^{\mathrm{A}}$ & $5.9 \pm 0.3^{\mathrm{B}}$ & $4.7 \pm 0.6^{\mathrm{C}}$ & $5.6 \pm 0.5^{\mathrm{B}}$ & $5.5 \pm 0.4^{\mathrm{BC}}$ & $6.1 \pm 0.4^{\mathrm{AB}}$ \\
\hline \multirow[t]{3}{*}{ Cabbage } & $4.7 \pm 1.2^{\mathrm{A}}$ & $4.0 \pm 1.2^{\mathrm{AC}}$ & $2.8 \pm 0.7^{\mathrm{BC}}$ & $3.0 \pm 0.7^{\mathrm{BC}}$ & $3.3 \pm 0.8^{\mathrm{BC}}$ & $3.1 \pm 0.9^{\mathrm{BC}}$ \\
\hline & \multicolumn{6}{|c|}{ Viable cell counts to coliform bacteria ( $\log \mathrm{CFU} / \mathrm{g})$} \\
\hline & Before washing & Distilled water & $\begin{array}{c}\text { Sodium } \\
\text { hypochlorite }\end{array}$ & $\begin{array}{l}\text { Ozone micro } \\
\text { bubble water }\end{array}$ & Ozonated water & Gaseous ozone \\
\hline Lettuce & $4.7 \pm 0.6^{\mathrm{A}}$ & $4.2 \pm 0.8^{\mathrm{A}}$ & $3.2 \pm 0.5^{\text {в }}$ & $3.8 \pm 0.8^{\mathrm{B}}$ & $3.6 \pm 0.8^{\mathrm{B}}$ & $4.6 \pm 0.7^{\mathrm{A}}$ \\
\hline Chinese cabbage & $5.0 \pm 0.9^{\mathrm{A}}$ & $4.5 \pm 0.8^{\mathrm{A}}$ & $3.5 \pm 0.7^{\mathrm{B}}$ & $3.8 \pm 0.6^{\mathrm{AB}}$ & $3.7 \pm 0.6^{\mathrm{AB}}$ & $4.7 \pm 0.4^{\mathrm{A}}$ \\
\hline Spinach & $5.9 \pm 0.5^{\mathrm{A}}$ & $5.3 \pm 0.7^{\mathrm{A}}$ & $4.0 \pm 1.0^{\mathrm{C}}$ & $5.2 \pm 0.7^{\mathrm{AB}}$ & $4.8 \pm 0.8^{\mathrm{ABC}}$ & $5.2 \pm 0.5^{\mathrm{A}}$ \\
\hline Cabbage & $3.6 \pm 1.3^{\mathrm{A}}$ & $3.4 \pm 1.2^{\mathrm{A}}$ & $2.7 \pm 0.6^{\mathrm{A}}$ & $2.9 \pm 0.9^{\mathrm{A}}$ & $2.7 \pm 0.7^{\mathrm{A}}$ & $3.1 \pm 1.0^{\mathrm{A}}$ \\
\hline
\end{tabular}

Un-inoculated vegetables were washed with each of the solutions or exposed to gaseous ozone (GO) for 3 min. Viable cells were enumerated after removing water by gentle spinning. The average value and standard deviation of the results evaluated from six trials are shown $(\mathrm{n}=24)$. The different letters on the shoulder for the same vegetables indicate significant difference $(\mathrm{P}<0.05)$.

Table 3. Effect of sanitizer washings on the visible quality of the vegetables.

\begin{tabular}{|c|c|c|c|c|}
\hline & \multicolumn{4}{|c|}{ Number of correct answers from a panel of 20 people } \\
\hline & $\begin{array}{c}\text { Sodium } \\
\text { hypochlorite }\end{array}$ & $\begin{array}{l}\text { Ozone micro } \\
\text { bubble water }\end{array}$ & Ozonated water & Gaseous ozone \\
\hline Lettuce & 10 & 9 & 7 & 6 \\
\hline Chinese cabbage & 3 & 5 & 11 & 6 \\
\hline Spinach & 10 & 9 & 9 & 6 \\
\hline Cabbage & 9 & 3 & 6 & 6 \\
\hline
\end{tabular}

Triangle tests were performed by using water-washed vegetables as a control. No significant difference in the color or appearance was observed among the three samples $(\mathrm{P}>0.05)$. 
4). Washing with DW, OW and OMBW reduced the surfaceattached E. coli $\mathrm{O} 157: \mathrm{H} 7$ by approximately 0.5 to $1.0 \mathrm{log}$ $\mathrm{CFU} / \mathrm{g}$, and after washing, no significant differences in viable bacterial cell count were observed between any of the tested vegetables. A 0.3 to $1.0 \mathrm{log} \mathrm{CFU} / \mathrm{g}$ higher bactericidal effectiveness was observed when a $100 \mathrm{mg} / \mathrm{L} \mathrm{NaClO}$ solution was used for washing compared to water. No change in the $E$. coli $\mathrm{O} 157: \mathrm{H} 7$ population was observed after exposure to 100 $\mathrm{mg} / \mathrm{L}$ GO. The results discussed above were not dependant on the kind of sanitizer used for the four kinds of vegetables.

The remaining bactericidal activity of the washing solution after a one-time use is shown in Table 5. The $\mathrm{NaClO}$

Table 4. Bactericidal effectiveness of sanitizers on dip-inoculated E. coli $\mathrm{O} 157: \mathrm{H} 7$ cells on the surface of leafy vegetables..

\begin{tabular}{|c|c|c|c|c|c|c|}
\hline & \multicolumn{6}{|c|}{ Viable cell counts enumerated by TSA-Rif agar medium (log CFU/g) } \\
\hline & Before washing & Distilled water & $\begin{array}{c}\text { Sodium } \\
\text { hypochlorite }\end{array}$ & $\begin{array}{l}\text { Ozone micro } \\
\text { bubble water }\end{array}$ & Ozonated water & Gaseous ozone \\
\hline Lettuce & $6.5 \pm 0.2^{\mathrm{A}}$ & $5.7 \pm 0.2^{\mathrm{B}}$ & $4.9 \pm 0.4^{\mathrm{C}}$ & $5.6 \pm 0.2^{\mathrm{B}}$ & $5.5 \pm 0.3^{\mathrm{B}}$ & $6.4 \pm 0.1^{\mathrm{A}}$ \\
\hline Chinese cabbage & $6.1 \pm 0.3^{\mathrm{A}}$ & $5.6 \pm 0.3^{\mathrm{B}}$ & $5.2 \pm 0.3^{\mathrm{CD}}$ & $5.3 \pm 0.2^{\mathrm{BD}}$ & $5.5 \pm 0.2^{\mathrm{B}}$ & $6.1 \pm 0.3^{\mathrm{A}}$ \\
\hline Spinach & $6.0 \pm 0.1^{\mathrm{A}}$ & $5.2 \pm 0.1^{\mathrm{B}}$ & $4.9 \pm 0.2^{\mathrm{C}}$ & $5.2 \pm 0.1^{\mathrm{B}}$ & $5.3 \pm 0.2^{\mathrm{B}}$ & $6.1 \pm 0.1^{\mathrm{A}}$ \\
\hline \multirow[t]{3}{*}{ Cabbage } & $5.5 \pm 0.2^{\mathrm{A}}$ & $4.7 \pm 0.3^{\mathrm{B}}$ & $3.7 \pm 0.6^{\mathrm{C}}$ & $4.3 \pm 0.3^{\mathrm{BD}}$ & $4.7 \pm 0.3^{\mathrm{B}}$ & $5.0 \pm 0.3^{\mathrm{BD}}$ \\
\hline & \multicolumn{6}{|c|}{ Viable cell counts enumerated by SMAC-Rif agar medium (log CFU/g) } \\
\hline & Before washing & Distilled water & $\begin{array}{c}\text { Sodium } \\
\text { hypochlorite }\end{array}$ & $\begin{array}{l}\text { Ozone micro } \\
\text { bubble water }\end{array}$ & Ozonated water & Gaseous ozone \\
\hline Lettuce & $5.6 \pm 0.2^{\mathrm{A}}$ & $4.7 \pm 0.3^{\mathrm{B}}$ & $4.2 \pm 0.6^{\mathrm{C}}$ & $4.9 \pm 0.5^{\text {B }}$ & $4.9 \pm 0.5^{\mathrm{B}}$ & $5.9 \pm 0.1^{\mathrm{A}}$ \\
\hline Chinese cabbage & $5.1 \pm 0.4^{\mathrm{A}}$ & $4.4 \pm 0.4^{\mathrm{A}}$ & $4.1 \pm 0.6^{\mathrm{B}}$ & $4.7 \pm 0.3^{\mathrm{AC}}$ & $4.4 \pm 0.5^{\mathrm{AB}}$ & $5.3 \pm 0.6^{\mathrm{AC}}$ \\
\hline Spinach & $5.5 \pm 0.6^{\mathrm{A}}$ & $4.5 \pm 0.2^{\mathrm{B}}$ & $4.4 \pm 0.4^{\mathrm{B}}$ & $5.0 \pm 0.4^{\mathrm{BC}}$ & $4.8 \pm 0.1^{\mathrm{BC}}$ & $5.8 \pm 0.2^{\mathrm{A}}$ \\
\hline Cabbage & $4.7 \pm 0.2^{\mathrm{A}}$ & $4.0 \pm 0.5^{\mathrm{B}}$ & $2.9 \pm 0.3^{\mathrm{C}}$ & $3.9 \pm 0.5^{\mathrm{B}}$ & $3.8 \pm 0.3^{\mathrm{B}}$ & $4.5 \pm 0.5^{\mathrm{AB}}$ \\
\hline
\end{tabular}

A cocktail of four strains of Escherichia coli $\mathrm{O} 157: \mathrm{H} 7$ was used to dip-inoculate vegetables, and the samples were washed as in Table 2. A high-recovery (Trypticase soy agar: TSA) and a low-recovery (Sorbitol MacConkey: SMAC) media supplemented with rifampicin (Rif) were used for enumeration. The average value and standard deviation of the results evaluated from four trials are shown ( $\mathrm{n}=12$ ). The different letters on the shoulder for the same vegetables indicate significant difference $(\mathrm{P}<0.05)$.

Table 5. Residual bactericidal activity of the washing solutions after use.

\begin{tabular}{|c|c|c|c|c|c|c|}
\hline & \multicolumn{6}{|c|}{ Viable cell counts enumerated by TSA-Rif agar medium (log CFU/g) } \\
\hline & \multicolumn{2}{|c|}{ Distilled Water } & \multicolumn{2}{|c|}{ Sodium hypochlorite } & \multicolumn{2}{|c|}{ Ozone micro bubble water } \\
\hline & Before use & After use & Before use & After use & Before use & After use \\
\hline Lettuce & $8.5 \pm 0.2^{\mathrm{A}}$ & $8.6 \pm 0.1^{\mathrm{A}}$ & $1.3 \pm 0.0^{\mathrm{B}}$ & $1.7 \pm 0.9^{\mathrm{B}}$ & $2.0 \pm 0.5^{\mathrm{B}}$ & $8.6 \pm 0.1^{\mathrm{A}}$ \\
\hline Chinese cabbage & $8.6 \pm 0.1^{\mathrm{A}}$ & $8.6 \pm 0.2^{\mathrm{A}}$ & $1.3 \pm 0.0^{\mathrm{B}}$ & $1.3 \pm 0.0^{\mathrm{B}}$ & $1.7 \pm 0.8^{\mathrm{B}}$ & $8.5 \pm 0.3^{\mathrm{A}}$ \\
\hline Spinach & $8.6 \pm 0.2^{\mathrm{A}}$ & $8.6 \pm 0.3^{\mathrm{A}}$ & $1.6 \pm 0.3^{\mathrm{B}}$ & $1.4 \pm 0.2^{\mathrm{B}}$ & $1.2 \pm 0.2^{\mathrm{B}}$ & $8.6 \pm 0.1^{\mathrm{A}}$ \\
\hline \multirow[t]{4}{*}{ Cabbage } & $8.5 \pm 0.2^{\mathrm{A}}$ & $8.6 \pm 0.2^{\mathrm{A}}$ & $1.7 \pm 0.6^{\mathrm{B}}$ & $2.0 \pm 0.9^{\mathrm{B}}$ & $1.8 \pm 0.8^{\mathrm{B}}$ & $8.6 \pm 0.1^{\mathrm{A}}$ \\
\hline & \multicolumn{6}{|c|}{ Viable cell counts enumerated by SMAC-Rif agar medium (log CFU/g) } \\
\hline & \multicolumn{2}{|c|}{ Distilled Water } & \multicolumn{2}{|c|}{ Sodium hypochlorite } & \multicolumn{2}{|c|}{ Ozone micro bubble water } \\
\hline & Before use & After use & Before use & After use & Before use & After use \\
\hline Lettuce & $8.3 \pm 0.2^{\mathrm{A}}$ & $8.4 \pm 0.3^{\mathrm{A}}$ & $1.3 \pm 0.0^{\mathrm{B}}$ & $1.7 \pm 0.8^{\mathrm{B}}$ & $1.7 \pm 0.5^{\mathrm{B}}$ & $8.5 \pm 0.2^{\mathrm{A}}$ \\
\hline Chinese cabbage & $8.3 \pm 0.1^{\mathrm{A}}$ & $8.3 \pm 0.2^{\mathrm{A}}$ & $1.5 \pm 0.2^{\mathrm{B}}$ & $1.7 \pm 0.6^{\mathrm{B}}$ & $1.6 \pm 0.6^{\mathrm{B}}$ & $8.2 \pm 0.3^{\mathrm{A}}$ \\
\hline Spinach & $8.4 \pm 0.2^{\mathrm{A}}$ & $8.4 \pm 0.3^{\mathrm{A}}$ & $1.3 \pm 0.1^{\mathrm{B}}$ & $1.3 \pm 0.1^{\mathrm{B}}$ & $1.6 \pm 0.5^{\text {B }}$ & $8.4 \pm 0.1^{\mathrm{A}}$ \\
\hline Cabbage & $8.3 \pm 0.2^{\mathrm{A}}$ & $8.3 \pm 0.2^{\mathrm{A}}$ & $1.5 \pm 0.2^{\mathrm{B}}$ & $1.7 \pm 0.6^{\mathrm{B}}$ & $1.7 \pm 0.7^{\mathrm{B}}$ & $8.3 \pm 0.1^{\mathrm{A}}$ \\
\hline
\end{tabular}

E. coli $\mathrm{O} 157: \mathrm{H} 7$ cells washed with PBS were mixed with vegetable washing solutions before and after use. After 3 min, the oxidative compound was neutralized by the addition of sodium thiosulfate and the viable cells were measured by TSA and SMAC. The average value and standard deviation of viable cells evaluated in three independent experiments $(n=6)$ are shown. The different letter on the shoulder of the values indicate significant difference $(\mathrm{P}<0.05)$. 
solution exhibited an $8.0 \log \mathrm{CFU} / \mathrm{mL}$ reduction in inoculated E. coli O157:H7 before and after its use. Conversely, the OMBW completely lost its bactericidal activity after one use. This result reflected the difference in chemical reactivity between ozone and hypochlorite. The chemical reactivity of ozone is higher than that of hypochlorite because the oxidation-reduction potential (ORP) of ozone and hypochlorite is $2.07 \mathrm{~V}$ and $1.63 \mathrm{~V}$, respectively. In addition, chloramine compound produced by the chemical reaction between hypochlorite and food has weak bactericidal activity, in contrast to oxygen produced by the reaction between ozone and food.

As shown in Table 1, the OMBW was able to reduce free E. coli $\mathrm{O} 157: \mathrm{H} 7$ cells by $7.4 \mathrm{log} \mathrm{CFU} / \mathrm{mL}$. However, a reduction of less than $2.0 \mathrm{log} \mathrm{CFU} / \mathrm{g}$ was achieved in the surface-attached bacteria of the vegetable. Zhang et al. (2005) reported a 0.8 to $1.7 \log \mathrm{CFU} / \mathrm{g}$ reduction in naturally attached bacteria on the surface of freshly cut celery by $\mathrm{OW}$ (0.03 to $0.18 \mathrm{mg} / \mathrm{L} \mathrm{O}_{3}$ ). Dipping iceberg lettuce into $4 \mathrm{mg} / \mathrm{L}$ of ozone-containing water for 2 min reduced the surface-attached mesophilic micro-organisms by $1.7 \mathrm{log} \mathrm{CFU} / \mathrm{g}$ (Akbas and Olmez, 2007). In other studies (Singh et al., 2002; Koseki and Isobe, 2006), OW (less than $16.5 \mathrm{mg} / \mathrm{L} \mathrm{O}_{3}$ ) exhibited similar or weaker bactericidal effectiveness compared to the $\mathrm{NaClO}$ solution on the surface-attached E. coli 157:H7 cells on shredded lettuce or baby carrots. In addition, no meaningful relationship between the bactericidal effectiveness of $\mathrm{OW}$ and exposure time was observed in this study. These results can be, at least partially, explained by the decomposition of dissolved ozone by reacting with organic materials. Restaino et al. (1995) have reported the in vitro effectiveness results with the addition of $20 \mathrm{mg} / \mathrm{L}$ bovine serum albumin (BSA) in ozone water to reduce the dissolved effective ozone concentration. The oxidative activity of the OMBW was stable for at least 6 months in water at $4^{\circ} \mathrm{C}$ (data not shown). However, once the vegetable was mixed with ozone OMBW, it easily lost its bactericidal activity, which was similar to the ordinary OW (Table 5). According to the evaluation experiments performed in a commercial lettuce washing facility, removing attached organic material from the leaves of vegetables by pre-washing was very important to prevent the reduction of dissolved ozone (Hassenberg et al., 2007).

As shown in Table 4, $100 \mathrm{mg} / \mathrm{L} \mathrm{NaClO}$ solution could reduce the attached $E$. coli $\mathrm{O} 157: \mathrm{H} 7$ cells on the surface of tested vegetables by 0.9 (Chinese cabbage) to 1.8 (Cabbage) $\log \mathrm{CFU} / \mathrm{g}$; this value was rather high compared to the OMBW and OW. These results were in agreement with others studies (Sapers, 2006; Baert et al., 2009; Gil et al., 2009) and were explained by the difference in molecular reactivity of these sanitizers. In contrast to the limited reduction level of surface-attached viable bacterial cells on vegetables, a higher bactericidal activity level was retained even after washing with $\mathrm{NaClO}$ (Tables 2, 4 and 5). This phenomenon may be, at least partially, explained by the restriction of mass transportation of the active compound around the area close to the surface of the vegetable (Elano et al., 2010). Briefly, the active compounds near the surface of vegetables rapidly react with organic materials and are used up. The supply of additional active compounds is thought to be restricted because of the viscosity of the fluid near the surface; mass transport is subjected to the concentration gradient of the active compound.

\section{Conclusion}

The effectiveness of OMBW to reduce viable bacterial cells of surface-attached bacteria on the four leafy vegetables tested was similar to ozonated water $(\mathrm{OW})$. The bactericidal activity of this sanitizer was completely lost after washing of the vegetables. A $100 \mathrm{mg} / \mathrm{L} \mathrm{NaClO}$ solution was shown to reduce surface-attached bacteria by approximately $2.0 \mathrm{log}$ $\mathrm{CFU} / \mathrm{g}$; a $7.0 \log \mathrm{CFU} / \mathrm{mL}$ reduction was achieved by using an in vitro washing solution. We concluded from these results that the use of OMBW or OW may provide only limited effectiveness for the decontamination of leafy vegetable surfaces and prevents cross-contamination via washing solutions compared to the use of the $100 \mathrm{mg} / \mathrm{L} \mathrm{NaClO}$ solution. However, the high stability of OMBW during storage might facilitate transport and supply of the chlorine alternative sanitizer to improve hygiene conditions at processing lines or processing environments of small and/or local facilities.

Acknowledgments This work was supported by a grant from the Ministry of Agriculture, Forestry and Fisheries of Japan (Research project for ensuring food safety from farm to table DI-7203).

\section{References}

Akbas, M.Y. and Olmez, H. (2007). Effectiveness of organic acid, ozonated water and chlorine dippings on microbial reduction and storage quality of fresh-cut iceberg lettuce. J. Sci. Food Agric., 87, 2609-2616.

Baert, L., Vandekinderen, I., Devlieghere, F., Van Coillie, E., Debevere, J. and Uyttendaele, M. (2009). Efficacy of sodium hypochlorite and peroxyacetic acid to reduce murine norovirus 1 , B40-8, Listeria monocytogenes, and Escherichia coli O157:H7 on shredded iceberg lettuce and in residual wash water. J. Food Prot., 72, 1047-1054.

Bari, M.L., Sabina Y., Kawamoto, S. and Isshiki, K. (2005). Microbial ecology of spoilage. In: Lamikanra, O.S.I. and Dike, U. (ed). "Produce degradation". CRC Taylor \& Francis, New York, pp. 379-419.

Barth, M., Hankinson, T.R., Zhuang, H. and Breidt, F. (2009). Mi- 
crobiological spoilage of fruits and vegetables. In: Sperber, W.H. and Doyle, M.P. (ed). "Compendium of the microbiological spoilage of foods and beverages". Springer, Georgia, pp. 135-183.

Beltran, D., Selma, M.V., Marin, A. and Gil, M.I. (2005). Ozonated water extends the shelf life of fresh-cut lettuce. J. Agric. Food Chem., 53, 5654-5663.

Buschini, A., Carboni, P., Furlini, M., Poli, P. and Rossi, C. (2004). Sodium hypochlorite-, chlorine dioxide- and peracetic acidinduced genotoxicity detected by the Comet assay and Saccharomyces cerevisiae D7 tests. Mutagenesis, 19, 157-162.

Cho, M, Kim, J, Kim, J.Y., Yoon, J. and Kim, J.-H. (2010). Mechanism of Escherichia coli inactivation by several disinfectants. Water Res., 44, 3410-3418.

Dhillon, B., Wiesenborn, D., Wolf-Hall, C. and Manthey, F. (2009). Development and evaluation of an ozonated water system for antimicrobial treatment of durum wheat. J. Food Sci., 74, E396E403.

Elano, R.R., Kitagawa, T., Bari, M.L., Kawasaki, S., Kawamoto, S. and Inatsu, Y. (2010). Comparison of the effectiveness of acidified sodium chloride (ASC) and sodium hypochlorite (NAClO) in reducing several Escherichia coli strains isolated from different retails food products. Foodborne Pathog. Dis., 7, 1481-1489.

Gil, M.I., Selma, M.V., López-Gálvez, F. and Allende, A. (2009). Fresh-cut product sanitation and wash water disinfection: problems and solutions. Int. J. Food Microbiol., 134, 37-45.

Hanning, I.B., Nutt, J.D. and Ricke, S.C. (2009). Salmonellosis outbreaks in the United States due to fresh produce: sources and potential intervention measures. Foodborne Pathog. Dis., 6, 635648.

Hassenberg, K., Idler, C., Molloy, E., Geyer, M., Plochl, M. and Barnes, J. (2007). Use of ozone in a lettuce-washing process: an industrial trial. J. Sci. Food Agric., 87, 914-919.

Heard, G.M. (2002). Microbiology of fresh-cut produce. In: Lamikanra, O. (ed). "Fresh-cut fruits and vegetables". CRC press. Florida, USA pp. 187-248.

Inatsu, Y., Bari, M.L., Kitagawa, T., Kawasak, S., Juneja, V.K. and Kawamoto, S. (2010a). The effect of repeated sodium hypochlorite exposure on chlorine resistance development in Escherichia coli O157:H7. Food Sci. Technol. Res., 16, 607-612.

Inatsu, Y., Kitagawa, T., Nei, D., Juneja, V.K. and Kawamoto, S. (2010b). Effectiveness of acidified sodium chlorite and other sanitizers to control Escherichia coli O157:H7 on tomato Surfaces. Foodborne Pathog. Dis., 7, 629-635.

Kondo, Y., Koizumi, Y., Iseki, M., Yamada, A., Takaoka, D., Takizawa, K., Yasuda, M. and Imai, H. (2005). Electric generation of available chlorine and ozone for sterilization by use of noble metal electrode. Surface Technol., 56, 34-40 (in Japanese).

Koseki, S. and Isobe, S. (2006). Effect of ozonated water treatment on microbial control and on browning of iceberg lettuce (Lactuca sativa L.). J. Food Prot., 69, 154-160.

Matthews, K.R. (2006) (ed). "Microbiology of fresh produce Emerging issues on food and safety". ASM Press. Washington, D. C., USA.

Nakamura, N. and Shiina, T. (2010). Application of micro / nano size bubble containing water for food industry. Food Develop. (Japan), 45, 9-11 (in Japanese).

Nei, D., Choi, J.W., Bari, M.L, Kawasaki, S., Kawamoto, S. and Inatsu, Y. (2009). Efficacy of chlorine and acidified sodium chlorite on microbial population and quality changes of spinach leaves. Foodborne Pathog. Dis., 6, 541-546.

Restaino, L., Frampton, E.W., Hemphill, J.B. and Palnikar, P. (1995). Efficacy of ozonated water against various food-related microorganisms. Appl. Environ. Microbiol., 61, 3471-3475.

Rico, D., Martín-Diana, A.B., Barat, J.M. and Barry-Ryan, C. (2007). Extending and measuring the quality of fresh-cut fruit and vegetables: a review. Trend Food Sci. Technol., 18, 373-386.

Sapers, G.M. (2006). Washing and sanitizing treatments for fruits and vegetables. In: Sapers, G.M., Gorny, J.R. and Yousef, A.E. (ed). "Microbiology of Fresh Produce". CRC Taylor and Francis. New York, pp. 3-32.

Singh, N., Singh, R.K., Bhunia, A.K. and Stroshine, R.L. (2002). Efficacy of chlorine dioxide, ozone, and thyme essential oil or a sequential washing in killing Escherichia coli O157:H7 on lettuce and baby carrots Lebensmittel-Wissenschaft Technol., 35, 720-729.

Stone, H. and Sidel, J.L. (2004). "Sensory Evaluation Practices" (3rd ed.). Elsevier Ltd. California, USA.

Stopforth, J.D, Mai, T., Kottapalli, B. and Samadpour, M. (2008). Effect of acidified sodium chlorite, chlorine, and acidic electrolyzed water on Escherichia coli O157:H7, Salmonella, and Listeria monocytogenes inoculated onto leafy greens. J. Food Prot., 71, 625-628.

Takahashi, M. (2005). The $\zeta$ potential of microbubbles in aqueous solutions - Electrical property of the gas-water interface -. J. Phys. Chem. B., 109, 21858-21864.

Takahashi, M., Kawamura, M., Yamamoto, Y., Ohnari, H., Himuro, S. and Shakutsui, H. (2003). Effect of shrinking micro-bubble on gas hydrate formation. J. Phys. Chem. B., 107, 2171-2173.

Wei, C.-W., Cook, D.L. and Kiek, J.R. (1985). Use of chlorine compounds in the food industry. Food Technol., Jan., 107-115.

Xu, Q., Nakajima, M., Ichikawa, S., Nakamura, N. and Shiina, T. (2008). A comparative study of microbubble generation by mechanical agitation and sonication. Innov. Food Sci. Emerg., 9, 489-494.

Zhang, L., Lu, Z., Yu, Z. and Gao, X. (2005). Preservation of freshcut celery by treatment of ozonated water. Food Control, 16, 279283. 